\title{
Five Centuries of Bible Translations into Kashubian
}

\section{ADAM RYSZARD SIKORA}

Adam Mickiewicz University in Poznań

arwejher@amu.edu.pl, ORCID: 0000-0002-0160-6894

\begin{abstract}
This paper discusses translations of biblical passages into Kashubian, which originated in the Lutheran circles between the 16th and the 19th centuries, followed by translations made in the Catholic circles in the 20th and the 21st centuries. The history of these translations has been divided into two periods: "old translations" and "contemporary translations." The former comprise various biblical texts preserved in manuscripts and printed monuments, which came into being between 1586 and the second half of the 19th century. The fundamental texts of this period include the works by Szymon Krofey (1586), Michał Pontanus (1643), and Perykopy smołdzińskie (1699-1701). The old translations were done from German in the Protestant circles in West Pomerania. In turn, the "contemporary translations" of biblical texts into Kashubian embrace translations from the second half of the 20th century, which were produced in the Catholic environment of Gdańsk Pomerania: from Latin (Mk 4:3-20) by Alojzy Nagel (1973), from Latin (four Gospels) by Rev. Franciszek Grucza (1992), from Polish (the New Testament and the Psalms) by Eugeniusz Gołąbek (1993-2007) and my own translations from Hebrew and Greek (the Four Gospels, the Pentateuch, Ecclesiastes) prepared in 2001-2020.
\end{abstract}

Keywords: Bible, Kashubian, translations, Pericopes of Smołdzino, biblical translation studies

The Kashubians belong to this type of regional cultural-ethnic group whose cultural axis or indigenous value is their language. Those who today (2020) actively use the Kashubian language are estimated at approx. 200-250 thousand. Although Kashubian has the status of a regional language in Polish law, ${ }^{1}$ linguists still discuss as to whether we are dealing with a language or only with a dialect.

The beginnings of the biblical translation tradition in Kashubia date back to the 16th century. However, there has been no comprehensive translation of the Holy Scriptures into Kashubian to this day although it should be noted that the past 25 years were characterized by increased activities in this field.

The history of biblical translations into Kashubian can clearly be divided into two periods: the first covering the 16th-19th centuries, when the first translations of biblical texts appeared mainly among the Kashubian population of the Lutheran faith,

1 Act of 6 January 2005 on national and ethnic minorities and on the regional languages, chapter IV, Art. 19 (Journal of Laws of 2005, No. 17, item 141). 
and the second period covering the 20th and the 21st centuries, the translators being Catholic Kashubians.

\section{Old Translations (16th-19th cc.)}

The oldest translations of the texts of the Holy Scriptures into Kashubian were found in Smołdzino, a small village in Pomerania, about $30 \mathrm{~km}$ north of Słupsk, at the end of the 19th century, when two researchers of Kashubian culture, the ethnographer Franz Tetzner and the linguist Friedrich Lorentz, discovered several monuments of Kashubian literature.

These were works of a religious nature, written (or translated) most likely by Lutheran clergymen in Kashubia in the 16th-18th centuries for the use of the local Kashubian population. They included: 1) "Duchowne pieśni” [Spiritual Songs] by Szymon Krofey; 2) "Mały Katechizm" [The Small Catechism] translated by Michał Mostnik; 3) "Zbiór perykop na niedziele i święta" [A Collection of Pericopes for the Sundays and Holy Days]; 4) "Śpiewnik starokaszubski" [Old Kashubian Songbook] and 5) "Zbiór różnych modlitw, pieśni, przemówień pogrzebowych, między innymi ze Smołdzina" [A Collection of Various Prayers, Funeral Speeches, including those from Smołdzino]. The first two were books printed in Gdańsk, while the rest were manuscripts. Besides "Śpiewnik starokaszubski," which was owned by a private person from Smołdzino, the works were housed in the archives of the parish church in Smołdzino. In the first half of the 20th century, they were acquired by the Library of the University of Greifswald, where they are kept at present, with the exception of "Zbiór różnych modlitw," whose location remains unknown. In the second half of the 20th century, thanks to two German publishers, Reinhold Olesch and Friedhelm Hinze, these monuments have new phototypic editions ("Duchowne pieśni,", "Mały katechizm," "Perykopy smołdzińskie" [The Pericopes of Smołdzino] $]^{4}$ and "Śpiewnik starokaszubski"). ${ }^{5}$ They have become the subject of detailed research by linguists and historians, both in Poland and abroad. From the biblical point of view, these monuments were topics of my analyses in a series of scientific articles ${ }^{6}$ and a monograph published in 2009.?

Olesch, S. Krofey. Geistliche Lieder.

Olesch, M. Pontanus. Der kleine Catechißmus.

Hinze, Die Schmolsiner Perikopen. The work is also on a CD in the Library of the Mikołaj Kopernik University in Toruń (Pracownia Pomorzoznawstwa CD 584).

5 Hinze, Altkaschubisches Gesangbuch.

6 For example, Sikora, “Teksty biblijne w Śpiewniku Szymona Krofeja z 1586 roku," 115-124; Sikora, "The Oldest Translations," 55-65; Sikora, "Przekłady tekstów biblijnych," 129-152.

7 Sikora, Teksty biblijne. 
Although these old works do not contain a comprehensive translation of even one book of the Bible, their numerous biblical fragments should be considered the oldest translations of the Holy Scriptures into Kashubian that have been found so far. These Kashubian texts, included in the old monuments, have been rendered from German.

\subsection{Translations by Szymon Krofey (1586)}

The oldest printed work with biblical fragments is a small cantional published in Gdańsk in 1586. Its title page gives information about the work and its author: Duchowne piesnie D. Marcina Luthera y ynszich naboznich męzow. Z niemieckiego w Slawięsky ięzik wilozone przes Szymana Krofea stuge slowa Bozego w Bytowie. Drukowano w Gdainsku przes Jacuba Rhode. Roku Panskiego 1586 [Spiritual Songs by D. Martin Luther and Other Pious Men. Translated from German into Slovincian by Szymon Krofey, Servant of God, in Bytów. Printed in Gdańsk by Jakub Rhode. Anno Domini 1586]. The book, including fragments of Scripture, was rendered from German into Slovincian (Polish: słowiński): $z$ niemieckiego w Slawięsky ięzik wilozone, by Szymon Krofey (ca. 1550-1590), who was the pastor of the Lutheran congregation in Bytów in the 1680s.

His Śpiewnik contains translations of biblical texts, mainly Psalmy i Kantyki [Psalms and Canticles], from German into Kashubian. In the first part of the cantional, there are 11 Psalms (12; 14; 46; 51; 67; 103; 124 [twice]; 127; 128; 130). Although the title "Psalm" indicates a biblical text, its close analysis leads to a conclusion that it is rather a paraphrase in the form of a song.

Krofey's Kancjonat also includes three canticles from Ewangelia św. Łukasza: Pieśn Maryi (Lucae 1), Pieśń Zachariasza (Lucae 2) i Pieśń Symeona (Lucae 2) [The Gospel of Saint Luke: Mary's Song of Praise (Luke 1), the Song of Zechariah (Luke 2) and the Song of Simeon (Luke 2)].

Apart from the songs, Śpiewnik comprises 25 short prayers. Most of them consist of two parts: an unmarked short biblical or liturgical fragment and a corresponding request to God. The Old Testament fragments used in the prayers are from, inter alia: Ps, Job, Isa and Jer, while the New Testament fragments include texts from Matt, Luke, John, Acts, Rom, 1 Cor and 1 Tim. However, these texts are not always faithful translations; sometimes they are paraphrases or specific compilations of several biblical texts combined with liturgical texts.

Krofey defined the language of the whole translation as slawiesky (Slovincian). There is no unanimity among scholars as to how exactly to define this language. Basically, the opinion is maintained that it is the ecclesiastical language of Kashubian Protestants used in Pomerania, which Krofey called slawięsky in order to distinguish it from the Polish language used by Catholics. ${ }^{8}$

8 Cf. Olesch, "Vorwort," S. Krofey. Geistliche Lieder, II; Neureiter, Historia literatury kaszubskiej, 24, 27; Treder, "Kaszubszczyzna dawnych przekładów," 311. 


\subsection{Translations by Michał Pontanus (1643)}

The second Pomeranian monument containing Kashubian biblical texts is Mały Katechizm Marcina Lutra [The Small Catechism of Martin Luther] translated by Michał Pontanus (born in ca. 1583, died in 1654), an Evangelical pastor in Smołdzino, a man who was thoroughly educated, in those times. He had extensive philological knowledge; in addition to Latin, he knew Hebrew, Greek and Syriac. ${ }^{9}$ The full title of the work is: In nomine Jesu. Parvus Catechismus D. Martini Lutheri Germanica Vandalicus. Der klenie Catechiszmus D. Martini Lutheri / Deutsch und Wendisch gegen einander gesetzt / Mit anhange der Sieben Busspsalmen Konig Davids. Mały Catechizm D. Marciná Lutherá Niemiecko-Wandalski ábo Slowięski / to jestá z Niemieckiego języká w Slowięski wystáwion y ná jáwnosc wydan / z Przydatkiem Siedm Psálmów Pokutnych krolá Dawida y inszych Potrzebnych rzeczi: osobliwie Historiy Passiy nászego Páná Jezusa według Ewangelistá Mattheuszá / y niektorych Piesn duchownych. Drukowány w Gdainsku przez Jerzego Rhetá / Roku Pánskiego $1643^{10}$ [In the Name of Jesus. The Small Catechizm by D. Martin Luther, German-Wendish or Slovincian, that is, from German to Slovincian executed and openly published, with the addition of King David's Seven Penitential Psalms and other useful things, especially the Story of the Passion of Jesus according to the Evangelist Matthew and with some spiritual songs. Printed in Gdańsk by Jerzy Rhetá in Anno Domini 1643].

The core of the monument consists of two printed parts: 1) Maty Katechizm Marcina Lutra, supplemented with Psalmy Pokutne Króla Dawida, from 1643 [The Small Catechism of Martin Luther, supplemented with the Penitential Psalms of King David, from 1643]; and 2) Pasja [The Passion] also printed in 1643 with Pieśni Kościelne [Church Songs]. The printed parts were bound with the so-called Dodatek [Supplement] to Pontanus, handwritten, probably in $1675 .{ }^{11}$ It is a catechism structured in the form of questions and answers on the subject of the faith.

The first part consists of Katechizm, Psalmy Pokutne (Siedm Psálmów Pokutnych krolá Dawida) and Modlitwa o odpuszczenie grzechów. The main biblical texts are obviously the penitential Psalms $(6 ; 32 ; 38 ; 51 ; 102 ; 130 ; 143)$.

The second part is Pasja according to Saint Matthew and seven liturgical songs (Cantiones). The first piece of this part is composed of a short, rhymed Passion arranged on the basis of the text of the four Gospels, followed by the biblical text of the Passion - two chapters from the Gospel of Saint Matthew (Mt 26:1-27:66).

Moreover, the whole Katechizm contains many biblical fragments, either single verses or whole periscopes. One can find citations from twelve OT books: Gen,

\footnotetext{
9 Cf. Tetzner, Die Slowinzen und Lebakaschuben, 133.

10 The editions of the book were published in 1758 and 1828, but their contents and titles were different. The fourth - phototypic - edition was made in Germany in 1958.

11 Cf. Lorentz, "Zur älteren kaschubischen," 559.
} 
Exod, Deut, 2 Chr, Ps, Prov, Wis, Syr, Isa, Jer, Joel and Zech. The NT citations come from sixteen books: Matt, Mark, Luke, John, Acts, Rom, 1 Cor, Gal, Eph, Col, 1 Thess, 1 Tim, 2 Tim, Titus, Heb and 1 Pet.

There are also fragments compiling various biblical texts. They appear when Katechizm refers three times to the texts on the institution of the Eucharist, combining verses from the Synoptic Gospels and 1 Corinthians. A similar procedure was applied to the topic of sending out the disciples. Here, there is a compilation of excerpts from Matthew and Mark. Matthew's text of Our Father is quoted twice.

The language of the work is defined on the title page of Mały katechizm as wandalski [Wendish] or slowięski [Slovincian]. ${ }^{12}$ Using this word, like Szymon Krofey in his work, the author could have wanted to emphasize the distinctiveness of this language in relation to the Polish language of the liturgy. In his Gramatyka Pomorska, Friedrich Lorentz thinks that the term slowięski does not mean the Slovincian of the turn of the 19th and 20th centuries, but the language of the Evangelical Slavs of Pomerania. ${ }^{13}$

\subsection{The Pericopes of Smołdzino (1699-1701)}

The third monument containing biblical texts is the so-called Perykopy smołdzińskie. It is mainly made up of biblical periscopes aimed to be read during sermons and services. Their translations were most probably produced by pastors of the West Pomeranian parishes in $1699-1701 .{ }^{14}$

Perykopy smołdzińskie published by Hinze is composed of two groups of texts. The first one is a collection of biblical periscopes - OT readings and Gospel readings (149 in total) arranged according to the chronology of the liturgical year, aimed to be read on subsequent Sundays and Holy Days. The periscopes are given in the language of the local Kashubians and in German. The collection begins with readings for the first Advent Sunday, and ends - on the 27th Sunday after the Solemnity of the Most Holy Trinity. The OT readings include periscopes from Isa (4) and Mal (1). Out of the 27 NT books, only seven do not appear in Perykopy smołdzinskie. ${ }^{15}$ The commonest Gospel periscopes come from Matthew and Luke, the rarest from Mark. There are 28 pericopes from Matthew, 4 from Mark, 26 from Luke and 17 from John. The Acts are quoted in 8 pericopes, Romans in 12, 1 Corinthians in 9, 2 Corinthians

12 Here the terms "wandalski" and "slowięski" are synonyms, by the first term is the Latin equivalent of the other. Cf. Mańczak, "Nazwa «słowiński»," 106-107.

13 Cf. Lorentz, Gramatyka pomorska, 2.

14 According to Friedrich Lorentz ("Zur älteren kaschubischen," 557), most of the text of Perykopy smoldzińskie was translated by one author - the pastor Jan M. Sporgius. Rev. Sporgius succeeded the son of Michał Pontanus, Tomasz, on the position of the parish priest of the church in Smołdzino in 1696-1720. Cf. Szultka, "Studia nad piśmiennictwem," 87.

15 There are no fragments from 2 Thess, Phlm, 1 and 2 Tim, 2 and 3 John and Jude. 
in 3, Galatians in 6, Ephesians in 6, Philippians in 4, Colossians in 2, 1 Thessalonians in 3, Titus in one, Hebrews in one, James in 2, 1 Peter in 6, 2 Peter in 2, 1 John in 3 and Revelation in one.

The second group of texts of Perykopy smołdzińskie comprises 14 occasional prayers, including Our Father as a faithful rendering of Matt 6:9-13. Moreover, there are four biblical passages: two from the Old Testament (Num 6:25-26 and Ps 106:1) and two from the New Testament (Matt 7:12 and 1 Cor 11:23-25).

Some scholars do not consider Perykopy smołdzińskie a Kashubian monument in the strict sense, similarly to the earlier linguistic monuments created in the Kashubian-Slovincian lands. ${ }^{16}$ They define the language of Perykopy smołdzińskie as the literary Polish of the 17th-century, with a mixture of individual Pomeranian dialectisms of greater or lesser intensity. ${ }^{17}$

\subsection{Old Kashubian Songbook (16th-18th cc.)}

The literary monuments written in Kashubian, containing biblical texts, include the so-called Śpiewnik starokaszubski [Old Kashubian Songbook], although according to linguists, ${ }^{18}$ the songbook contains fewer forms and words in the Kashubian language than, for example, the songbook by Szymon Krofey or Perykopy smołdzińskie. ${ }^{19}$ In this songbook there are poems, the creation of which Hinze dates back to the 16th and 18th centuries. ${ }^{20}$ In his opinion, most of these works are translations from German. Almost 3/5 of them are reworked versions of the songs from Krofey's Duchowne pieśni. ${ }^{21}$ In the songbook, we find ten songs based on the motives of the biblical Psalms: 1; 30; 51; 103; 124 (two different versions), 127; 130 (two different versions) and 147 . Their adaptations in the German version were ascribed to six authors, whose first and last names were mentioned. ${ }^{22}$ Like in Krofey's Pieśni, it is difficult to recognise these pieces as translations of the biblical texts since they are more or less free paraphrases, often very elaborated as compared with the original.

16 Cf. Popowska-Taborska, "Uwagi o języku Perykop smołdzińskich," 34.

17 Cf. Zieniukowa, [rev.] "Die Schmolsiner Perikopen," 162.

18 Cf. Zieniukowa, "Die Sprache," 78.

19 Cf. Zieniukowa, "Die Sprache," 78.

20 Cf. Hinze, "Einleitung," Die Schmolsiner Perikopen, IX.

21 Cf. Zieniukowa, "Polszczyzna tekstów religijnych," 114.

22 The authors of the parahrases of the Psalms were: Martin Luther (1488-1546) - Ps 124 and two versions of Ps 130; Erhart Hegenwalt (1524) - Ps 51; Johann Kolrose († 1558) - Ps 127; Justus Jonas (1524) - Ps 124; Paul Gerhardt (1607-1679) - Ps 1; Johann Gramann (1540) - Ps 103. No authors' names were given for song 79 (Ps 30) and song 111 (Ps 147). 


\subsection{The Translations of Our Father and the Parable of the Sower from Luke 8:4-15 (19th c.)}

Our Father (Matt 6:9-13) is one of the most frequently translated biblical fragments into Kashubian. Besides its oldest versions coming from the works by Szymon Krofey, by Michał Pontanus or from Perykopy smołdzińskie, there are a number of independent versions. They include the so-called Ojcze nasz [Our Father] from Szczenurze before the year 1840, Wójćenaś by Florian Ceynowa from 1861, Ojcze nasz in Slovincian, also from the 19th century, Ojcze nasz from 1835 made by pastors: Ernst F. Döhling and Auagust T. Kummer ${ }^{23}$ and Ojcze nasz from ca. 1840 by Izmaił Sriezniewski, ${ }^{24}$ Ojcze nasz by Marcin Pollex, ${ }^{25}$ by Rev. Aleksander Świeczkowski from Żarnowiec ${ }^{26}$ and by F. Lorentz from Witków. ${ }^{27}$

In the mid-19th century, the Russian linguist Aleksander Hilferding noted two versions of the parable of the sower from the Gospel of Saint Luke (8:4-15). The first one was dictated from memory to him by a Slovincian fisher, while the other, also given from memory, by "a certain old man from the land of Bytów."28

\section{Contemporary Translations}

In the 20th and the 21st centuries, several Bible translators, both clergy and lay people, belonging to the Catholic Church, translated smaller or larger parts of the Holy Scriptures.

\subsection{Alojzy Nagel (1930-1998)}

The chronologically first author of a contemporary translation was Alojzy Nagel, one of the most outstanding Kashubian poets of his generation. In a book by Jan Drzeżdżon, published in 1986, Alojzy Nagel stated, "In the mid-1960s, the Bible Society in London asked me to translate the New Testament into Kashubian. I took up this job, but due to lack of time I have not been able to complete it." ${ }^{29}$

It is difficult to establish what part of the translation Alojzy Nagel managed to accomplish. In fact, only one pericope from the Gospel of Saint Mark (4:3-20) was most

\footnotetext{
23 Cf. Szultka, "Nowe źródła," 148.

24 Cf. Srezniewskij, "Zamečanija o nareiji kašebskom," 52-60.

25 Tetzner, Die Slawen in Deutschland, 440.

26 Cf. Tetzner, Die Slawen in Deutschland, 468.

27 Cf. Lorentz, Slovinzische Texte, 47.

28 Cf. Hilferding, Resztki Słowian, 131.

29 Drzeżdżon, Wspótczesna literatura kaszubska, 277.
} 
likely translated from Latin; the periscope was included in Kaschubische Antologie by Ferdinand Neureiter, and published in Munich in 1973. ${ }^{30}$

\subsection{Rev. Franciszek Grucza (1911-1993)}

Rev. Franciszek Grucza belonged to the literary-ideological group called Zrzeszeńcy [Associationists], who emphasized the linguistic distinctiveness of the Kashubians. ${ }^{31}$ We do not know when exactly he began translating biblical texts. In 1991, the printing house Hlondianum in Poznan published the four Gospels separately, ${ }^{32}$ and in 1992 they appeared in one volume as Kaszëbskô Biblëjô. ${ }^{33}$ Nowi Testament. IV Ewanjelje. Rev. Grucza's translation bore the imprimatur of Archbishop Tadeusz Gocłowski of Gdańsk and the nihil obstat of Bishop Jan Szlaga. As stated by Rev. Grucza, the basis for his translation was the Latin version, the so-called Neo Vulgate (1970). ${ }^{34}$ Rev. Grucza's translation met with a lively response from linguists. Critical assessments of his translation were not uniform: some scholars considered this translation as unsuccessful, while others assessed it positively. ${ }^{35}$ A favourable opinion about the translation was expressed by Bishop Professor Jan Szlaga, who wrote, inter alia, "Personally, I have the impression that the special mark and beauty of the language of this translation were determined by the skilful archaization of the Kashubian language. In my opinion, it is accurate. From the theological point of view, the translation is correct, and the archaization of the language gives it a special solemnity, which should characterize any translation of the Bible and the biblical language itself. I even believe that Rev. Grucza's translation made a successful attempt to create biblical Kashubian. I highly appreciate the accuracy of this translation; the introductions and footnotes are also good." ${ }^{36}$ Undoubtedly, this translation has already found its permanent place both in the history of literary translations ${ }^{37}$ and in the history of the translation of biblical texts into Kashubian, as the first Kashubian translation of the four Gospels in the Catholic Church.

\footnotetext{
30 Cf. Neureiter, Kaschubische Anthologie, 280.

31 Cf. Treder, “Tłumaczenia Biblii," 278.

32 Grucza, Ewanjeliô sw. Mateusza; Grucza, Ewanjeliô sw. Marka; Grucza, Ewanjeliô sw. Łukasza; Grucza, Ewanjeliô sw. Jana.

33 Grucza, Kaszëbskô Biblëjô.

34 However, in his philological analysis of the translation, Edward Breza ("Biblia po kaszubsku," 23) showed that the author followed the Polish version of Biblia Tysiaclecia.

35 Cf. Treder, “Tłumaczenia Biblii,” 289.

36 Grucza, Kaszëbskô Biblëjô, 6.

37 Since some linguists do not see any religious value in this translation, only a literary value. So, e.g. Breza, "Język przekładu Ewangelii," 324.
} 


\subsection{Eugeniusz Gołąbek (1949-)}

In 1993, a year after Rev. Franciszek Grucza's rendering, the entire New Testament was translated by Eugeniusz Gołąbek ${ }^{38}$ (b. 1949), an electrician by profession, and a passionate columnist and musician. Gołąbek's translation was issued with the consent of the 245th Diocesan Bishops' Conference.

In 1999, Eugeniusz Gołąbek published the Book of Psalms. ${ }^{39}$ This translation is preceded by the Decree of the Primate of Poland, Józef Cardinal Glemp. In 2007, a lectionary by E. Gołąbek was published in Gdańsk, bearing the title To je Słowò Bòżé Czëtania mszalné i spiéwë midzëlekcyjné na niedzele i swiãta we wszëtczich czadach lëturgicznëch rokù na kaszëbsczi przełożi Eugeniusz Gòłąbk [This is the Word. Readings and Chants for the Sundays and Holy Days from All the Seasons of the Liturgical Year. Translated into Kashubian by Eugeniusz Gołąbek].

In the introduction to his New Testament, Eugeniusz Gołąbek explains that he produced the translation from Polish since he did not know Greek and Latin. ${ }^{40}$ In their forewords two bishops: Marian Przykucki and Jan Szlaga, expressed their high opinions about this rendering. Bishop Przykucki stressed the translator's skill to render Kashubian idioms.

The translation was received by theologians and linguists with appreciation and approval. It is generally evaluated with the translation by Rev. Franciszek Grucza. In such an approach, it is obvious that both translations fit in the two currents of the literary evolution of the Kashubian language, which are still vibrant today. Eugeniusz Gołąbek's translation should be seen within the movement referring to the Polish language, with a spelling similar to Polish and a long tradition, reaching even the 16th century. In turn, Rev. Franciszek Grucza's translation appears to be part of the second movement, emphasizing the cultural and linguistic distinctiveness of the Kashubians, including their own spelling.

\subsection{My Own Translations (2001-2020)}

An essential novelty of my translations is that they have been done from the original

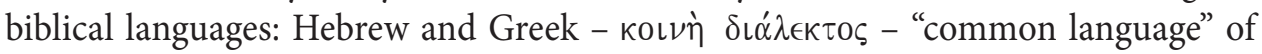
the Hellenized ancient world. ${ }^{41}$ In my translation work I have used the contemporary critical editions of the Hebrew Bible and the New Testament. ${ }^{42}$

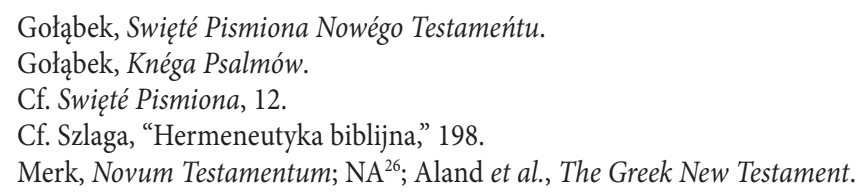


My first publication was the translation of the Gospel of Mark from Greek into Kashubian in 2001 ${ }^{43}$ : Ewanielëjô wedle swiãtégò Marka. This text had the imprimatur of the Primate of Poland Józef Cardinal Glemp.

Two years later I published Ewangelia Dzieciństwa (Matt 1-2; Luke 1-2) and Prolog Ewangelii według św. Jana (John 1:1-14) ${ }^{44}$ in Poznań, within the project Verba Sa$\mathrm{cra} .{ }^{45}$ In the following years translations of the two next Gospels appeared, namely, in 2007 - Ewanielëjô wedle swiâtégò Jana with the imprimatur of Archbishop Tadeusz Gocłowski, and in 2009 - Ewanieliô wedle swiâtégò Mateùsza, in 2010 - Ewanieliô wedle swiâtégò Łukôsza with the imprimatur of Archbishop Stanisław Gądecki. These translations were also reviewed by Rev. Prof. Jan Perszon and Prof. Jerzy Treder.

In 2010, all the four Gospels, which I have translated, were published in one volume under the title Ewanielie na kaszëbsczi tolmaczoné [The Gospels Translated into Kashubian]. It is a revised text, harmonized with its earlier editions, with more extensive introductions and commentaries. A nihil obstat to this edition was given by Bishop Jan Szlaga. From this edition comes the text of the Magnificat on a ceramic tablet, hung by the Kashubians in the Church of the Visitation in Ain Karem, Israel, in March 2013.

The first biblical texts that I translated from Hebrew were the Psalms. In the next three editions of Verba Sacra. Biblia kaszubska [Verba Sacra. The Kashubian Bible], in 2011, 2012 and 2013, a total of 31 psalms were published. For the January 2014 edition, I prepared and put to print translations of selected fragments from the Book of Genesis.

In 2015, the whole Book of Genesis (Knéga Zôczątków) ${ }^{46}$ was issued. In the foreword, Archbishop Stanisław Gądecki wrote, "It is an extremely valuable achievement because so far only the first three chapters of this book have been translated - almost four hundred years ago by Michał Pontanus - from German into Kashubian, and in modern times, the translation of nine fragments of the Book of Genesis from Polish into Kashubian - for the purposes of the publication of the Kashubian Lectionary in 2007 - was undertaken by Eugeniusz Gołąbek. Thanks to Father Adam Sikora’s striving for maximum faithfulness of the translation, Knéga Zôczątków is characterized by theological correctness; and the consistent use - by this biblical scholar who is well known not only in the region of Wielkopolska - of current language standards in the Kashubian translation, along with the implementation of the characteristics

43 Sikora, Ewanielëjô wedle swiãtégò Marka.

44 Sikora, „Ewangelie Dzieciństwa,” 15-30.

45 The initiative of the Poznan film director Przemysław Basiński, aiming at presenting biblical texts by outstanding Polish actors. The venue of the presentation is the cathedral in Poznan. The first edition of Verba Sacra took place in the Jubilee Year 2000. Between 2004 and 2019 within the Wejherów branch of Verba Sacra - Biblia Kaszubska there were 17 editions during which biblical texts in Kashubian were read by Danuta Stenka.

Sikora, Knéga Zôczątków. 
of "home" Kashubian, yielded a translation of the first OT book that is very close to contemporary spoken Kashubian."

Each next year brought a publication of another book of the Pentateuch. Thus the Book of Exodus (Knéga Wińdzeniô) ${ }^{47}$ was published in 2016, and in 2017 - the Book of Leviticus (Knéga Kapłańskô), ${ }^{48}$ in 2018 - the Book of Numbers (Knéga Lëczbów) ${ }^{49}$ and in 2019 - the Book of Deuteronomy (Knéga Pòwtórzonégò Prawa). ${ }^{50}$ All the works had the imprimatur of Archbishop Stanisław Gądecki, based on the theological opinion written by Rev. Prof. Jan Perszon; they were published by the Main Board of the Kashubian-Pomeranian Association in Gdańsk and the Faculty of Theology of the Adam Mickiewicz University in Poznań.

In 2020, my translation of the Book of Qoheleth (Knéga Koheleta) ${ }^{51}$ in two language versions (Polish and Kashubian) was published, also authorised by Archbishop Gądecki on the basis of the theological opinions of Rev. Prof. Stefan Szymik and Rev. Prof. Jan Perszon. The publisher was the Faculty of Theology of the Adam Mickiewicz University in Poznań.

The late linguist, Prof. Jerzy Treder (1943-2015) from the University of Gdańsk reviewed my translations many times. After the publication of the Gospel according to Saint Mark, this eminent expert on the Kashubian language, stated, "in general [...] also this translation [...] is part of the previous disputes about the shape of the general, standardized literary Kashubian." ${ }^{2}$ In the context of the translations by Rev. F. Grucza and E. Gołąbek, this translation, in Treder's opinion, "complies the rules of the latest spelling, which is a system placed between the other versions, as to the degree of its distinctiveness from the Polish spelling" and "as for the syntax, Sikora's text is closer to Gołąbek's version and also to the Polish version of Biblia Tysiąclecia." In turn, in the linguistic layer "the translation has undoubted features of Central-Western Kashubian and the features of the language of the Associationists, and thus both reflect the language of Grucza's translation." However, "in terms of phraseology, ${ }^{53}$ Sikora's translation more frequently complies with Gołąbek's text, thus approaching Polish, and departing from Grucza's rendering." ${ }^{54}$ Generally, this version, like the earlier translation by E. Gołąbek, should be seen within literary Kashubian, reaching even the 16th century tradition, referring to Polish. In the conclusion to his review of Ewanielie na kaszëbsczi tolmaczoné, Prof. J. Treder stated, "Formally, in the light of the Vatican II documents, accepting only translations of the Holy Scriptures from

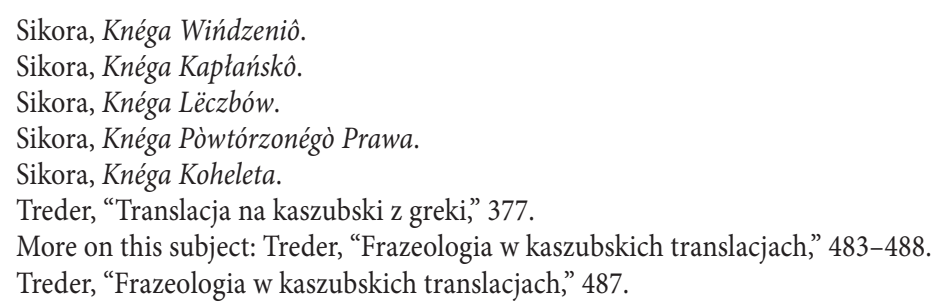


the original texts, the Kashubian translation by Father Sikora appears as the only one in the so-called official circulation. Naturally, the renderings by Gołąbek and Grucza fully retain their historical, cultural, missionary and educational significance, and from a linguistic point of view, they can still play a significant role as a reference point for new translations; they will constantly confirm whether the Kashubian language can meet the requirements specified for it by all the texts contained in the Bible."55 Reviewing the translation of the Book of Genesis, J. Treder wrote, "The translator tries to translate literally, philologically precisely, abandoning any linguistic experiment. He successfully imitates the specificities of the original biblical text and also in most cases reproduces faithfully the peculiar expressive combinations of words and syntactic structure of the original, e.g. with the dominance of parataxis and other syntactic constructions, the one with no conjunctions and the one repeating simple conjunctions, such as 'and' and 'but.' It is not a mere coincidence that the Kashubians speak similarly at home." ${ }^{56}$ The eminent Czech linguist and theologian Josef Bartoň echoes, "Therefore, the text of the translation largely reflects the formal structure of the original - its simple syntax (e.g., the dominant parataxis, a language close to colloquial spoken Kashubian) or the preservation of some vivid lexical-phraseological equivalents, i.e. traditional Semitisms." ${ }^{\text {7 }}$

\section{Biblical Texts Translated into Kashubian}

The amount of biblical texts translated into Kashubian, distinguishing between the so-called old translations (16th-19th centuries) and contemporary translations (20th and 21st centuries):

\begin{tabular}{|l|l|l|}
\hline $\begin{array}{c}\text { Biblical } \\
\text { book }\end{array}$ & \multicolumn{1}{|c|}{ OLD TRANSLATIONS } & \multicolumn{1}{|c|}{ CONTEMPORARY TRANSLATIONS } \\
\hline \multicolumn{3}{|c|}{ OLD TESTAMENT } \\
\hline Gen & $1: 27-28.31 ; 2: 18.21-24 ; 3: 16-19$ & the whole book \\
\hline Exod & $18: 21 ; 20: 3.5 .7-17$ & the whole book \\
\hline Lev & & the whole book \\
\hline Num & $6: 25-26$ & the whole book \\
\hline Deut & $6: 6-7 ; 10: 18$ & the whole book \\
\hline Josh & & $5: 9 a \cdot 10-12 ; 24: 1-2 \mathrm{a} .15-17.18 \mathrm{~b}$ \\
\hline 1 Sam & & $\begin{array}{l}3: 3 \mathrm{~b}-10.19 ; 12: 1.7-10.13 ; 16: 1 \mathrm{~b} .6-7.10-13 \mathrm{a} ; \\
26: 2.7-9.12-13.22-23\end{array}$ \\
\hline
\end{tabular}

55 Sikora, Ewanielie na kaszëbsczi tołmaczoné, 321.

56 Treder, "O języku kaszubskim," 122.

57 Bartoň, "Další svazek kašubské bible," 40-44. 
FIVE CENTURIES OF BIBLE TRANSLATIONS INTO KASHUBIAN

\begin{tabular}{|c|c|c|}
\hline $\begin{array}{c}\text { Biblical } \\
\text { book }\end{array}$ & OLD TRANSLATIONS & CONTEMPORARY TRANSLATIONS \\
\hline \multicolumn{3}{|c|}{ OLD TESTAMENT } \\
\hline 2 Sam & & 5:1-3; 7:1-5.8b-12.14a.16 \\
\hline $1 \mathrm{Kgs}$ & & $\begin{array}{l}\text { 3:5.7-12; 8:41-43;17:10-24; } \\
\text { 19:4-9a.11-13.16b.19-21 }\end{array}$ \\
\hline $2 \mathrm{Chr}$ & & 4:8-11.14-16a.42-44; 5:14-17 \\
\hline $2 \mathrm{Chr}$ & $19: 6-7$ & $36: 14-16.19-23$ \\
\hline Neh & & $8: 1-4 a \cdot 5-6.8-10$ \\
\hline $2 \mathrm{Macc}$ & & $7: 1-2.9-14$ \\
\hline Job & $19: 25$ & $19: 1.23-27 \mathrm{a}$ \\
\hline Ps & $\begin{array}{l}\text { 2:10-11; 6:1-11;24:7; 32:1-11;34:12;38:1-23; } \\
\text { 51:1-21; 102:1-29; 103:10;124; 127; 128; } \\
\text { 130:1-8; 143:1-12; 145:2.15-16;118:1; } \\
\text { 147:9-11 }\end{array}$ & the whole book \\
\hline Prov & $13: 24 ; 18: 22 ; 22: 6 ; 23: 13$ & 8:22-35; 9:1-6; 31:10-13.19-20.30-31 \\
\hline Qoh & & the whole book \\
\hline Wis & $6: 10$ & $\begin{array}{l}1: 13-15 ; 2: 12.17-20.23-24 ; 3: 1-6.9 ; 6: 12-16 ; \\
9: 13-18 b ; 11: 22-26 ; 12: 1-2.13 .16-19 ; 18: 6-9\end{array}$ \\
\hline Sir & $2: 15 ; 7: 1.23$ & $\begin{array}{l}3: 2-6.12-14.17-18.20 .28-29 ; 15: 15-20 ; \\
24: 1-2.8-12 ; 27: 4-7.30 ; 28: 7 ; 35: 12-14.16-18\end{array}$ \\
\hline Isa & $\begin{array}{l}\text { 1:16-17; 7:10-15; 9:1-6; 40:1-5; 43:25; 49:23; } \\
53: 4-6 ; 55: 6 ; 60: 1-6\end{array}$ & $\begin{array}{l}\text { 2:1-5; 5:1-7; 6:1-2a.3-8; 7:10-14; 8:23b; 9:1-3.5-6; } \\
\text { 11:1-10;22:19-23; 25:6-10a; 35:1-7a.10; } \\
\text { 40:1-5.9-11; 42:1-4.6-7; 43:16-22.24b-25; } \\
\text { 45:1.4-6; 49:1-6.14-15; 50:4-9; 52:7-10.13-15; } \\
\text { 53:1-12; 54:4a.5-14; 55:1-11; 56:1.6-7; } \\
\text { 58:7-10; 60:1-6; 61:1-2a.10-11; 62:1-5.11-12; } \\
\text { 63:16b-17.19b; 64:3-7; 66:10-14c.18-21 }\end{array}$ \\
\hline Jer & $4: 1 ; 14: 20$ & $\begin{array}{l}1: 4-5.17-19 ; 17: 5-8 ; 20: 7-13 ; 23: 1-6 ; 31: 7-9.31-34 ; \\
33: 14-16 ; 38: 4-6.8-10\end{array}$ \\
\hline Bar & & 3:9-15.32-38; 4:1-4; 5:1-9 \\
\hline Ezek & & $\begin{array}{l}2: 2-5 ; 17: 22-24 ; 18: 25-28 ; 33: 7-9 ; 34: 11-17 \\
36: 16-17 a .18-28 ; 37: 13-14\end{array}$ \\
\hline Dan & & $7: 9-10.13-14 ; 12: 1-3$ \\
\hline Hos & & 2:16.17b.21-22; 6:3-6; 11:1.3-4.8c-9 \\
\hline Joel & $2: 12$ & $1: 13 ; 2: 12-18$ \\
\hline Amos & & 6:1a.4-7; 7:12-15 \\
\hline Jonah & & 3:1-5.10 \\
\hline Mic & & $5: 1-4$ \\
\hline $\mathrm{Hab}$ & & $1: 2-3 ; 2: 2-4$ \\
\hline Zeph & & $2: 3 ; 3: 12-18$ \\
\hline Zech & $1: 3$ & $2: 14-17 ; 9: 9-10 ; 12: 10-11$ \\
\hline Mal & $3: 1-4$ & 1:14b; 2:1-2b.8-10; 3:1-4.19-20a \\
\hline
\end{tabular}




\begin{tabular}{|c|c|c|}
\hline $\begin{array}{l}\text { Biblical } \\
\text { book }\end{array}$ & OLD TRANSLATIONS & CONTEMPORARY TRANSLATIONS \\
\hline \multicolumn{3}{|c|}{ NEW TESTAMENT } \\
\hline Matt & $\begin{array}{l}2: 1-15 ; 3: 13-17 ; 4: 1-11 ; 5: 20-26 ; \\
6: 9-13.24-34 ; 7: 7.12 .15-23 ; 8: 1-13.23-28 ; \\
9: 1-8.18-26 ; 10: 10 ; 11: 2-10 ; 13: 24-30 \\
\text { 15:21-28; 17:1-9; 18:1-11.15-18.23-35; } \\
20: 1-16 ; 21: 1-16 ; 22: 1-22.34-46 ; 23: 34-39 ; \\
24: 15-28 ; 25: 1-13.31-46 ; 16: 1-75 ; 27: 1-66 ; \\
28: 19\end{array}$ & the whole book \\
\hline Mark & $7: 31-37 ; 8: 1-9 ; 10: 13-19 ; 16: 1-8.14-20$ & the whole book \\
\hline Luke & $\begin{array}{l}\text { 1:26-80; 2:1-52; 5:1-11; 6:36-42; } \\
\text { 7:11-17.48.50; 8:4-15; 10:16.23-37; 11:14-28; } \\
\text { 14:1-11.16-24; 15:1-10; 16:1-9.19-31; } \\
\text { 17:11-19; 18:9-14.31-43; 19:41-48; } 21: 25-36 ; \\
24: 13-47\end{array}$ & the whole book \\
\hline John & $\begin{array}{l}\text { 1:1-14.19-28; 2:1-11; 3:1-21; 4:47-54; } \\
\text { 6:1-15; 8:46-59; 10:1-16; 11:25-26; 14:23-31; } \\
\text { 15:11.26-27; 16:1-27; 20:17.19-29; } 21: 15-24\end{array}$ & the whole book \\
\hline Acts & $\begin{array}{l}\text { 1:1-11; 2:1-13; 5:29; 6:8-15; 7:1-2.51-60; } \\
\text { 8:14-17; 10:34-48; } \\
\text { 13:26-33 }\end{array}$ & the whole book \\
\hline Rom & & the whole book \\
\hline 1 Cor & $\begin{array}{l}1: 4-9 ; 4: 1-5 ; 5: 6-8 ; 9: 24-27 ; 10: 1-13 \\
11: 23-32 ; 12: 1-11 ; 13: 1-13 ; 15: 1-10\end{array}$ & the whole book \\
\hline 2 Cor & $3: 4-11 ; 6: 1-10 ; 11: 19-33 ; 12: 1-9$ & the whole book \\
\hline Gal & $\begin{array}{l}3: 15-29 ; 4: 1-7.21-31 ; 5: 16-26 \\
6: 1-10\end{array}$ & the whole book \\
\hline Eph & $3: 13-21 ; 4: 1-6.22-28 ; 5: 1-9.15-29 ; 6: 1-17$ & the whole book \\
\hline Phil & $1: 3-11 ; 2: 5-11 ; 3: 17-21 ; 4: 4-7$ & the whole book \\
\hline Col & 1:9-14; 3:12-17.19 & the whole book \\
\hline 1 Thess & $4: 1-7.13-18 ; 5: 1-13$ & the whole book \\
\hline 2 Thess & & the whole book \\
\hline $1 \mathrm{Tim}$ & $2: 1-3 ; 3: 1-6 ; 5: 5-6.17-18$ & the whole book \\
\hline 2 Tim & $3: 14-15$ & the whole book \\
\hline Titus & $2: 11-15 ; 3: 1.5-7$ & the whole book \\
\hline Phlm & & the whole book \\
\hline Heb & $9: 11-15 ; 10: 38 ; 13: 17$ & the whole book \\
\hline Jas & $1: 16-27$ & the whole book \\
\hline 1 Pet & $2: 2.11-18.21-25 ; 3: 1.3 .6-15 ; 4: 8-19 ; 5: 5-11$ & the whole book \\
\hline 2 Pet & $1: 16-21 ; 3: 3-13$ & the whole book \\
\hline 1 John & $3: 13-18 ; 4: 16-21 ; 5: 4-10$ & the whole book \\
\hline 2 John & & the whole book \\
\hline 2 John & & the whole book \\
\hline Rev & $12: 7-12$ & the whole book \\
\hline
\end{tabular}


The above table shows that the whole OT books translated into Kashubian include: Genesis, Exodus, Leviticus, Numbers, Deuteronomy, Psalms and Qoheleth. No passage has been translated from thirteen OT books, namely from Judges, Ruth, 1 Chronicles, Ezra, Tobit, Judith, Esther, 1 Maccabees, Song of Songs, Lamentations, Obadiah, Nahum and Haggai; all of the New Testament books have been translated.

Although the process of translating the Bible into Kashubian is in progress, there is still a considerable lack of translations of the whole Old Testament or its significant portion. Clearly, there are few translations from the original biblical languages. Apart from the Pentateuch and the Book of Ecclesiastes, no other book has been translated from the Old Testament in its entirety. On the other hand, from the New Testament, apart from the four Gospels, the three Epistles of Saint John and Revelation, the remaining 19 books have not yet been translated from Greek.

This overview of the published translations of larger or smaller parts of the Holy Scriptures into Kashubian shows that over the past five centuries, i.e. from the first known printed Kashubian biblical text, the number of translations has not been very impressive. After the first undertakings of translating the Bible into Kashubian, which were related to the Protestant Slovincian milieus, only the last half-century was a period of significant achievements in this field. The translations of the biblical texts into Kashubian, created in the 20th century by Rev. Franciszek Grucza, Eugeniusz Gołąbek and by me, can be placed within two existing currents in the literary evolution of the Kashubian region. The literary current referring to the Polish language, with a spelling similar to Polish and a long tradition, reaching even the 16th century, embraces Eugeniusz Gołąbek's translations and mine. On the other hand, the translation by Rev. Franciszek Grucza, emphasizing the ethnic and linguistic distinctness of the Kashubians, visible in their own spelling, belongs to the second literary current.

Translated by Maria Kantor

\section{Bibliography}

\section{Translations into Kashubian}

Gołąbk, E. (trans.), Swięté Pismiona Nowégo Testameńtu. Na podstawie Biblii Tysiąclecia (wyd. III popr., 1982) (Gdańsk: Zrzeszenie Kaszubsko-Pomorskie. Zarząd Główny - Pelplin: Wydawnictwo Diecezjalne w Pelplinie 1993).

Gołąbk, E. (trans.), Knéga Psalmów. Na pòdstawie Biblii Tysiąclecia (wyd. IV, 1989) (Gdańsk: CZEC 1999).

Grucza, F. (trans.), Ewanjeliô sw. Jana (Poznań: Hlondianum 1992).

Grucza, F. (trans.), Ewanjeliô sw. Łukasza (Poznań: Hlondianum 1992).

Grucza, F. (trans.), Ewanjeliô sw. Marka (Poznań: Hlondianum 1992). 


\section{ADAM RYSZARD SIKORA}

Grucza, F. (trans.), Ewanjeliô sw. Mateusza (Poznań: Hlondianum 1992).

Grucza, F. (trans.), Kaszëbskô Biblëjô. Nowi Testament. IV Ewanjelje, z łacënë przełożëł na kszëbszci jazëk ks. Franciszek Grucza (Poznań: Hlondianum 1992).

Sikora, A.R. (trans.), Ewanielëjô wedle swiãtégò Marka. Pierwsze tłumaczenie Ewangelii z języka greckiego na język kaszubski (Gdańsk - Nałęczów - Poznań: Zarząd Główny Zrzeszenia Kaszubsko-Pomorskiego 2001).

Sikora, A.R. (trans.), „Ewangelie Dzieciństwa (tłum. z j. greckiego na kaszubski J 1,1-14; Mt 1-2; Łk 1-2)," Verba Sacra. Biblia kaszubska. Ewangelie Dzieciństwa (Poznań: Biuro Organizacyjne Verba Sacra 2003) 15-30.

Sikora, A.R. (trans.), Ewanielie na kaszëbsczi tołmaczoné (Gdańsk: Zarząd Główny Zrzeszenia Kaszubsko-Pomorskiego 2010).

Sikora, A.R. (trans.), Knéga Zôczątków. Z hebrajsczégò jãzëka na kaszëbsczi przełożił Adam Ryszard Sikora. Księga Rodzaju. Tłum. z języka hebrajskiego na język kaszubski (Gduańsk: Zrzeszenie Kaszubsko-Pomorskie. Zarząd Główny 2015).

Sikora, A.R. (trans.), Knéga Wińdzeniô. Exodus. Z hebrajsczégò jãzëka na kaszëbsczi przełożit Adam Ryszard Sikora (Gduńsk: Zrzeszenie Kaszubsko-Pomorskie Zarząd Główny 2016).

Sikora, A.R. (trans.), Knéga Kapłańskô. Leviticus. Z hebrajsczégò jãzëka na kaszëbsczi przełoził Adam Ryszard Sikora (Gduńsk: Zrzeszenie Kaszubsko-Pomorskie. Zarząd Główny 2017).

Sikora, A.R. (trans.), Knéga Lëczbów. Numeri. Z hebrajsczégò jãzëka na kaszëbsczi przełożił Adóm Riszard Sykòra (Gduńsk: Zrzeszenie Kaszubsko-Pomorskie. Zarząd Główny 2018).

Sikora, A.R. (trans.), Knéga Pòwtórzonégò Prawa. Deuteronomium. Z hebrajsczégò jãzëka na kaszëbsczi przełożił ò. Adóm Riszard Sykòra ÒFM (Gduńsk: Zrzeszenie Kaszubsko-Pomorskie. Zarząd Główny 2019).

Sikora, A.R. (trans.), Knéga Kòheleta. Księga Koheleta. z języka hebrajskiego na język polski i kaszubski przettumaczył i przypisami opatrzył o. Adam R. Sikora OFM (Poznań: Uniwersytet im. Adama Mickiewicza Wydział Teologiczny 2020).

\section{Studies}

Aland, K. - Black, M. - Martini, C.M. - Metzger, B.M. - Wikgren, A., The Greek New Testament, 3 ed. (Stuttgart: Deutsche Bibelgesellschaft 1983).

Bartoň, J., "Další svazek kašubské bible - kniha Genesis," Opera Slavica 25/4 (2015) 40-44.

Breza, E., "Język przekładu Ewangelii na kaszubski ks. Franciszka Gruczy," Studia z Filologii Polskiej i Słowiańskiej 32 (1995) 301-324.

Breza, E., "Biblia po kaszubsku," Język kaszubski. Poradnik encyklopedyczny (ed. J. Treder) (Gdańsk: CZEC 2002) 22-23.

Drzeżdżon, J., Współczesna literatura kaszubska. 1945-1980 (Warszawa: Ludowa Spółdzielnia Wydawnicza 1986).

Hilferding, A., Resztki Słowian na południowym wybrzeżu Morza Bałtyckiego (Gdańsk: Zrzeszenie Kaszubsko-Pomorskie 1989).

Hinze, F. (pub.), Altkaschubisches Gesangbuch (Berlin: Akademie-Verlag 1967).

Hinze, F. (pub.), Die Schmolsiner Perikopen (Berlin: Akademie-Verlag 1967).

Lorentz, F., "Zur älteren kaschubischen Literatur," Archiv für Slavische Philologie 20 (1898) 556-577.

Lorentz, F., Slovinzische Texte (Petersburg: Otdelenija Imperatorskoj Akademii Nauk 1905). 
Lorentz, F., Gramatyka pomorska. 1. Wstęp. Źródła. Transkrypcje. Z mapa narzeczy pomorskich (kaszubskich) (Poznań: Instytut Zachodnio Słowiański 1927).

Mańczak, W., "Nazwa «słowiński»," O pochodzeniu i dialekcie Kaszubów (ed. W. Mańczak) (Gdańsk: CZEC 2002) 106-114.

Merk, A. (ed.), Novum Testamentum Graece et Latine, 9 ed. (Romae: Pontifitium Institutum Biblicum 1964).

Nestle, E. - Nestle, E. - Aland, K., Novum Testamentum Graece, 26 ed. (Stuttgart: Deutsche Bibelgesellschaft 1979).

Neureiter, F., Historia literatury kaszubskiej. Próba zarysu (Gdańsk: Zrzeszenie Kaszubsko-Pomorskie. Oddział Miejski 1982).

Neureiter, F., Kaschubische Anthologie (München: Sagner 1973).

Olesch, R. (pub.), M. Pontanus. Der kleine Catechißmus D. Martini Lutheri. Deutsch vnnd Wendisch gegen einander gesetzt. Mit anhange der Sieben Bußpsalmen König Davids, Danzig 1643 und Passionsgeschichte, Danzig 1643 (Köln - Graz: Böhlau 1958).

Olesch, R. (pub.), S. Krofey. Geistliche Lieder D. Martin Luthers und anderer frommer Männer. Duchowne piesnie D. Marcina Luthera y ynßich naboznich męzow. Danzig 1586 (Köln Graz: Böhlau 1958).

Popowska-Taborska, H., “Uwagi o języku Perykop smołdzińskich,” Język Polski 48/1 (1968) 33-40.

Sikora, A.R., "Przekłady tekstów biblijnych na kaszubski. Historia. Stan aktualny. Perspektywy," Scripta Biblica et Orientalia 5 (2013) 129-152.

Sikora, A.R., “Teksty biblijne w Śpiewniku Szymona Krofeja z 1586 roku. Najstarsze fragmenty Pisma Świętego po kaszubsku?," Studia Franciszkańskie 15 (2005) 115-124.

Sikora, A.R., "The Oldest Translations of Biblical Texts into Kashubian," Poznańskie Studia Teologiczne 22 (2008) 55-65.

Sikora, A.R., Teksty biblijnew najstarszych zabytkach piśmiennictwa kaszubskiego (XVI-XVIII w.) (Poznań: Wydawnictwo WT UAM 2009).

Srezniewskij, I.I., “Zamečanija o nareiji kašebskom," Izvestiia Akademii Nauk. Seriia literatury i iazyka 56/1 (1997) 52-60.

Szlaga, J., „Hermeneutyka biblijna”, Wstęp ogólny do Pisma Świętego (red. J. Szlaga) (Poznań Warszawa: Pallottinum 1986).

Szultka, Z., "Studia nad piśmiennictwem «starokaszubskim,» w szczególności Michała Brüggemanna alians Pontanusa albo Mostnika. I. Pochodzenie Michała Brüggemanna," Slavia Occidentalis 45 (1988) 61-89.

Szultka, Z., "Nowe źródła z dziejów Kaszubów i ich języka w I połowie XIX wieku," Rocznik Gdański 54/1 (1994) 119-176.

Tetzner, F., Die Slowinzen und Lebakaschuben. Land und Leute, Haus und Hof. Sitten und Gebräuche. Sprache und Literatur im östlichen Hinterpommern (Berlin: Felber 1899).

Tetzner, F., Die Slawen in Deutschland, Beiträge zur Volkskunde der Preussen, Litauer und Letten, der Masuren und Philipponen, der Tschechen, Mährer und Serben, Polaben und Slovinzen, Kaschuben und Polen (Braunschweig: Vieweg 1902).

Treder, J., "Kaszubszczyzna dawnych przekładów tekstów biblijnych," Symbolae slavisticae. Dedykowane Pani Profesor Hannie Popowskiej-Taborskiej (ed. E. Rzetelska-Feleszko) (Warszawa: Slawistyczny Ośrodek Wydawniczy 1996) 309-315. 
Treder, J., “Tłumaczenia Biblii na język kaszubski,” Biblia w kulturze. Materiały z sesji zorganizowanej przez Katedrę Filologii Polskiej WSP w Stupsku i Wyższe Seminarium Duchowne w Koszalinie (ed. S. Rzepczyński) (Słupsk: Wydawnictwo Uczelniane WSP 1996) 273-293.

Treder, J., “Translacja na kaszubski z greki (na podstawie Ewangelii św. Marka)," Język religijny dawniej i dziś. Materiały z konferencji. Gniezno 15-17 sierpnia 2002 (eds. S. Mikołajczyk - T. Węcławski) (Biblioteczka Poznańskich Studiów Polonistycznych Serii Językoznawczej 21; Poznań: Poznańskie Studia Polonistyczne 2004) 370-378.

Treder, J., "Frazeologia w kaszubskich translacjach Ewangelii," De lingua et litteris. Studia In honorem Casimiri Andreae Sroka (eds. D. Stanulewicz - R. Kalisz - W. Kürschner) (Gdańsk: Wydawnictwo Uniwersytetu Gdańskiego 2005) 483-488.

Treder, J., "O języku kaszubskim Knédżi Zôczątków w przekładzie o. prof. dra hab. Adama R. Sikory OFM," Knéga Zôczątków. Z hebrajsczégò jãzëka na kaszëbsczi przełożił Adam Ryszard Sikora (Gduńsk: Zrzeszenie Kaszubsko-Pomorskie. Zarząd Główny 2015) 121-123.

Zieniukowa, J., [rev.] "Die Schmolsiner Perikopen. Herausgegeben von Friedhelm Hinze. Berlin 1967, Akademie-Verlag, p. XX, 176. Deutsche Akademie der Wissenschaften zu Berlin. Veröffentlichungen des Instituts für Slawistik. Herausgegeben von H. H. Bielfeld. Nr 41, Poradnik Językowy 2 (1968) 161-163.

Zieniukowa, J., "Die Sprache des «Altkaschubischen Gesangbuches» und der «Schmolsiner Perikopen»," Zeitschrift für Slawistik 14 (1969) 77-85.

Zieniukowa, J., "Polszczyzna tekstów religijnych z obszaru dialektu słowińskiego spisanych między XVI a XVIII wiekiem," Polszczyzna regionalna wokresie renesansu ibaroku (eds. H. Wiśniewska - C. Kosyl) (Wrocław: Zakład Narodowy im. Ossolińskich. Wydawnictwo Polskiej Akademii Nauk 1984) 113-121. 